\title{
Juan Bautista Villalpando and the nature and science of architectural drawing
}

\begin{abstract}
In 1604, Jesuit priest and architect Juan Bautista Villalpando published In Ezechielem Explanationes. ${ }^{*}$ It was a massive three volume scriptural exegesis on the Book of Ezekiel. Volume Two was dedicated to the reconstruction of Ezekiel's vision of the Temple of Solomon. This volume consists of five books: on the prophecy on the Temple; its plan and reconstruction; the justification of the reconstruction; its bronzes and ornamentation, and an entire book on the nature and science of architectural drawing. Initially the latter appears out of place in a Scriptural exegesis but he explained that the purpose of this book was in order to guide the theologians so that they can form a mental idea or image of Temple, for their understanding and enlightenment of the entire Temple. However, throughout the text he points to the utility of the book to architects. For Villalpando the laws of optics were essential to the norms of perspective. Moreover, the sense and structure of seeing was a crucial element to the norms of mathematic and architecture, it is also a central theme in his theology. This paper examines his theory and his propose of perspective for architecture drawing.
\end{abstract}

\section{Introduction}

In Ezechielem Explanationes was to be a collaboration by two Spanish Jesuit priests, Jerónimo del Prado and Juan Bautista Villalpando. It was Prado's project and Villalpando's role was a minor one, he was to provide a reconstruction of the Temple to coincide with Prado's text. However the early death of Prado, after the completion of Volume One, left the entire project for Villalpando to complete on his own. Volume Two and Three are entirely written by Villalpando [Morrison, 2009: 1, 12-13]. Surviving correspondence reveals that Prado and Villalpando disagreed on the design of the Temple [Arroyo-Furphy and Tolton, 2009]. It is very possible that if Prado had lived Solomon's Temple would not have dominated the entire Volume Two and the reconstruction would have been subordinate to Prado's Scriptural exegesis.

In Ezekiel's vision of the Temple his spirit is guided by an Angel through the Temple, measuring the walls, the courtyards, the altar and so on. The prophet does not claim that the temple he described is Solomon's, he only claimed that it is a vision of the Temple of Jerusalem. Traditionally the description in the Biblical texts of 1 Kings and the Second Book of Paralipomenon are taken to be Solomon's Temple and the text of Ezekiel to be a vision of a future Temple. However, Villalpando claimed that Ezekiel's vision was the Temple of Solomon and he made no distinction between Solomon's Temple and the vision of Ezekiel. He used 1 Kings, Second Book of Paralipomenon, and the Book of Ezekiel, as describing the same building [Villalpando, 2009: 133-141]. When the measurements of these Biblical texts did not equate to each other, Villalpando made complex explanations to demonstrate that if they were examined in a different way, they were in fact the same [Villalpando, 2009: 349-361]. Villalpando's use of Ezekiel's vision caused an outcry within the Jesuit order. Pope Sixtus V set up an Inquisition commission, headed by Cardinal Toledo, to examine Villalpando's thesis. At the same time General Father Aquaviva also conducted an inquiry by appointing a committee of the Father of

\footnotetext{
* The quotations from In Ezechielem Explanationes are translated from Latin by the author
} 
the Society of Jesuits to examine Villalpando's orthodoxy. In the end Villalpando was cleared of any suspicion of heresy, but he continued not to make any distinction between Solomon's Temple and Ezekiel's vision [Morrison, 2009. 10-11].

The illustrations are an integral part of the entire text of Ezechielem Explanationes. Villalpando claimed that

"I have not studied it (the Temple) in order to re-establishing the old" "glory of the Temple, but in order to interpreting the texts of the" "Scriptures that contain the sublime mysteries of our religion; my" "intention was to clarify everything that is the object of our sensorial" "comprehension of this information to discover other more divine" "elements [Villalpando and Prado, 1604: vol. 2, prologue unpaginated]."

To 'clarify everything that is the object of our sensorial comprehension' there are fortyeight copperplate engravings, twenty of these folded out with some that are over one and half metres wide. These engravings are of exceptionally fine quality, and reproduced the plans, elevations and perspective drawings. Villalpando gathered together a team of highly skilled artists and engravers from Rome and Flanders at the workshops in some rooms of the Roman College, his residence in Rome. None of the engravings are signed and in his text Villalpando claimed "I have drawn", clearly claiming to be the artist. Although Villalpando closely supervised the works he did not do any of the etching himself [Morrison, 2009: 18-20]. One of the engraving plates 'The Egyptian Night' was inscribed 'Graphic method f', the name scraped and burnished away with great effort, although the deliberate deletion is partially visible [Ripoll, 1991: 270]. Perhaps Villalpando felt that it was 'his' reconstruction and that he was the artist of this reconstruction. However, Villalpando believed that the original plans of the Temple were drawn by the Divine hand of God.

"It deserves also our praise that God with his hand drew the design, the" "figures, the location of all the elements, the graphic plan, the elevations"

"and perspectives; and besides that God described all of it with abundant"

"comments that were delivered to David, at the same time, was given to"

"Solomon so that the artisans could carried it out all to perfection

[Villalpando and Prado; 1604: 104].”

For Villalpando it was the "Architecture of Theology [Villalpando and Prado, 1604: Vol 2, Prologue, unpaginated]," which revealed the mind and plans of God. To contemplate or meditate to visualize, was an attempt to reveal the truths within. Ignatius of Loyola, founder of the Jesuit order, promulgated this concept in his Spiritual Exercises, 1544-5. In Spiritual Exercises he presented a set of contemplation exercises, which emphasises the use of the five senses of the imagination. Seeing is the dominate senses, his contemplation exercises begin with the words 'Composition, seeing the place.' Ignatius stated that; "composition consists in seeing through the gaze of the imagination the material place [Ignatius of Loyola, 1996: 294]." On a meditation of hell he claimed that the "composition here is to see with the eyes of the imagination the length, breadth and depth of hell [Ignatius of Loyola, 1996: 298]." In a prayer of the senses he asserted that

"To see the persons with the imaginative sense of sight, meditating and" "contemplating their circumstances in detail, and to draw some profit" “from what I see [Ignatius of Loyola, 1996: 307].” 
Ignatius drew 'some profit' not only from 'seeing' the narrative but also places and buildings. To see or conceive these holy places or narratives was to come closer to an understanding of the Sacred Scriptures.

Villalpando did perceive the significance of the standards and norms of the Architecture of Theology, which would clarify the conditions and the essential requirements of the Architect. He formed a very concise theory on the nature and science of architectural drawings and its importance. This theory was "to instruct a theologian and not a labourer [Villalpando and Prado: vol 2, 47]" and the images were "in order to guide the theologians so that they can form a mental idea or image of Temple [Villalpando and Prado, 1604: Vol 2, prologue, unpaginated],” for their understanding and enlightenment of the entire Temple; but although Villalpando emphasised the spiritual application of his theory the practical application of it was ever present. The sacred was the model for the profane; and architectural drawings were an essential form of communication of the architect. The architect must not only 'see' by contemplation the entire building to be built but must be able to communication that sight.

\section{Villalpando's Nature and Science of architectural drawing}

Villalpando considered Vitruvius' nature of architectural drawing that was called

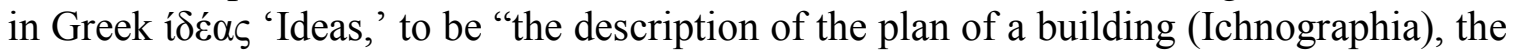
elevation (Orthographia) the perspective (Scenographia) [Villalpando and Prado, 1604: vol 2, prologue, unpaginated].” He quoted Vitruvius' description of perspective: “It is the drawing of the facade and of the side parts of the building as being moved away toward a point where all the visual lines corresponds [Villalpando and Prado, 1604: vol.2, 62].” Villalpando claimed that interpreters of Vitruvius including Daniele Barbaro believed that the term should be 'sciographia,' and not 'scenographia.' Sciographia is a "term that signifies a sketch, a planned and shaded painting, where the lines represent an empty and deceitful form of the objects [Villalpando and Prado, 1604: vol.2, 62].” What Cicero calls a 'shaded sketch.' But this form of drawing is only useful to painters and not to architects. It is only

"perspective that puts in sight the whole and all of the parts of the"

"building, its limits, its projections, the doors and the gates as well as all"

"the other elements, by means of its graphic expression of lines and"

"although all these lines concur in a point; on the other hand, in a"

"painting it is simply shaped so that you can barely distinguish the limits"

"that are moving away from the objects and the ones that are in sharp"

"view [Villalpando and Prado, 1604: vol.2, 62]."

Villalpando believed that drawings that were guided by the rules of optics were the only useful tool for producing architectural plans. Painting can give a lifelike image but it was not a good tool for the architect and although painters and architects can have the use of perspective in common there is a distinct difference in its use. The drawings of an architect results in a building that is a copy or perfect imitation of the drawing produced, while the drawings of the painter consist in an imitation of the building, which already exists, reproducing its colours, the stone and the textures [Villalpando and Prado, 1604: vol.2, 42]. In this discussion of perspective for painting and architecture, Villalpando appears to be criticising Alberti for not drawing a distinction between the use 
of perspective and architecture in De Pictura [Alberti, 1972]; however, Villalpando does not mention him by name.

But light and the science of vision are the study of nature and therefore it is considered to be a study of philosophy. The philosopher considers the nature of light, its movement, its production or its corruption of objects; where as the "teacher of perspective examines the vision or light, its limits, its lines, its surfaces, its points, its figure, its sections, its directions in straight lines, and he supports the nature of light as the Philosophers say [Villalpando and Prado, 1604: 48].” There are two categories of science of light: the first is to speculate, this is the realm of the philosopher; the second is to make it pragmatic, this is the realm of the architect.

Villalpando used Aristotelian terminology, such as 'species' and 'power [Aristotle, 1965],' in a framework of Euclidian optics. “The visual thing is called power, the visible thing is called object, because it acts on the power through its form [Villalpando and Prado, 1604: vol 2, 52]." The forms or species are an immaterial affect that illuminate the environment, this environment moves the power so that vision can be carried out but not the vision of the species but the vision of the objects of the ones that are the species these would not be able to be seen if the species are not transmitters to the power.

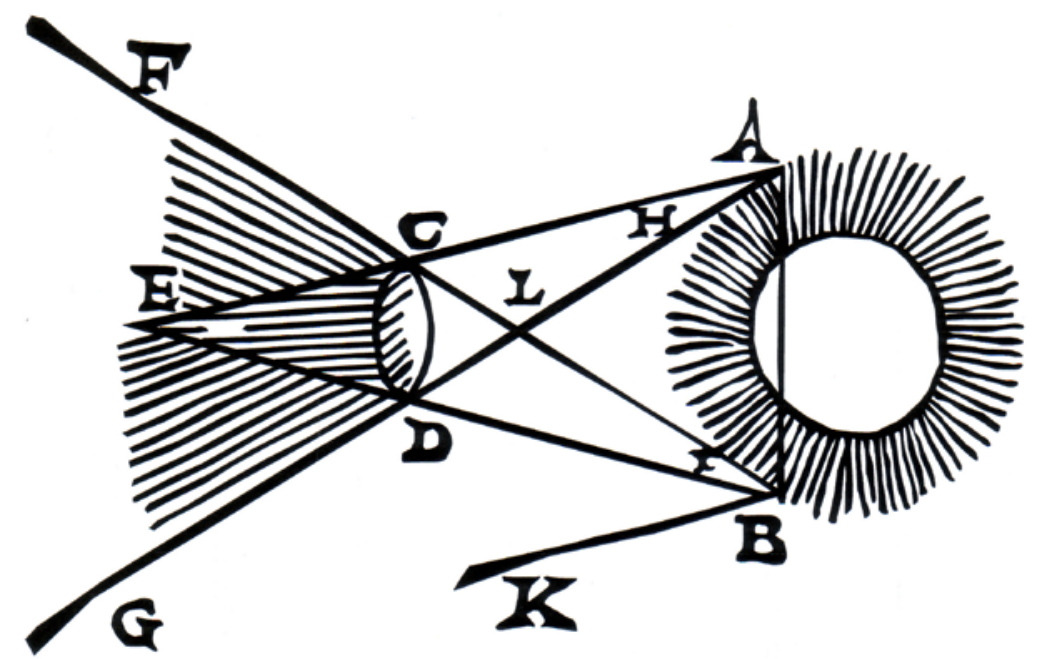

Figure 1: A graphic demonstration of the angles of movement of light

Villalpando engages in a lengthy discussion on the angles of the movement and action of light, and more importantly the angles of the areas in total shadows or defused light (Figure 1). This theory of physics; that light does not mix, is shared by the teachers of perspective because

"it is observed that light that moved from the two luminous bodies follow a" "dual pathway, each in a straight line on the paths to each one of the" "luminous bodies and also because the shadows are moving separately from" "the opaque bodies [Villalpando and Prado, 1604: vol 2, 50]."

The shadows will always be larger than the body that produces them when the luminous body is smaller that the body that produces the shadow. If in figure one the only light comes from the arc $\mathrm{AH}$, it will projected the shadow of the body $\mathrm{CD}$ within the space ECDG that will always be larger the more it moves away from the straight line CD, since 
the straight line EA and GH are extended to the point A, there are found and from a triangle whose base is $\mathrm{CD}$; under this base you consider the shadow, it is impossible to draw a line equal to or smaller than CD that can touch both lines CE, DG easily, as it can be shown by lines parallel to $C D$.

This environment moves to the power so that the vision can be carried out, although not the vision of the species but the vision of the objects of the ones that are species. The transmission of forms is the same as the movement of light. The species are sent, as light are in a straight line.

"The species of the objects are transmitted only to those places in which the" "objects themselves are present, that is to say, by means of a few straight" "lines from the objects towards the places to where the species must be" "transmitted [Villalpando and Prado, 1604: vol 2, 49]."

Vision is carried out in the same way,

"around the straight line that would be drawn from the object seen to the" "centre of the visual power through the pupil of the eye: this is what the" "teachers in perspective call 'perpendicular line' to this straight line. It" "should be understood that through this line the visual species arrives to the" "eye and also through this same line leave the "spirits' positioned from the" "eye to the object seen [Villalpando and Prado, 1604: vol 2, 50]."

Figure 2: Villalpando's cone of vision

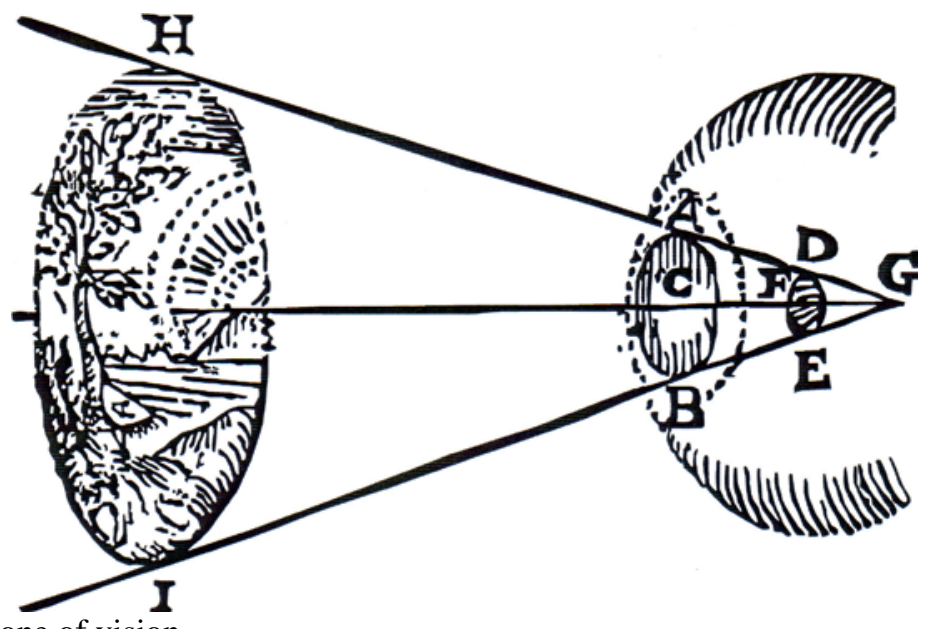

In figure two Villalpando examined the vision of objects. He demonstrated that the laws of optics affirm that the rays are emanated from the eye by means of lines, separated from each other by a small distance. Those rays touch the object seen in the cone: the base of this cone is the seen the object, the vertex is situated in the eye and the greater the angle of this vertex the greater the area seen.

"The circle $A B$, is the hole of the pupil, whose centre will be $C$; and the" "small circle DE, is the liquid organ of the vision, the centre will be F;" " $\mathrm{CG}^{\dagger}$ is joined for a straight unlimited line that is called axis or" "perpendicular line, and by the points $\mathrm{A}$ and $\mathrm{D}$ of the circles $\mathrm{AB}, \mathrm{DE}$," "will correspond with the axis; they will be joined through a straight"

\footnotetext{
${ }^{\dagger}$ This was written as CE in the original text
} 
"unlimited line AD that will cut to the axis in the point D. And" "remaining motionless at the point G surrounding itself the straight one" "GA until it returns to its place of origin: there remains to describe, a" "cone, by the movement of this line and this cone covers everything that" "the eye can see in a straight vision; if we think that the cone finishes in" "the visible object, the base of this cone will be HI [Villalpando and Prado, 1604: 57-58].”

Villalpando stated that the architect cannot derive a building of dignity and elegance if the architect does not have in their mind the totality of the building they want to construct. But the architect must translate their vision from a "mere consideration of the distinct parts which does not seem sufficient to contemplate mentally the symmetry, the beauty, the order, the proportion and other aspects that are given in the confrontation of all the building and of its parts." The architect must convert their mental image by means of lines "so that once captured in a drawing one could see such images and you can see another and be able to compare them, judge and perfect them [Villalpando and Prado, 1604: vol 2, 61].”

"Perspective can be understood to be like the description of the stage. The" "stage is that part of the theatre that extends between the two extremes, that" "is to say, all that appears before the eyes of the one that contemplates that" "middle part of the theatre, and this can neither take shape nor be expressed" "with either lines or with colours unless the method of optics is realized [Villalpando and Prado, 1604: vol 2, 63].”

The architect must translate their ideas in perspective that belongs to the norms of optics: that is to provide the division or section of the cone of vision and of the proposed plan. Since perspective's purpose is to place the lines in a given surface, "so that its species excite the vision exactly the same as it excited the species of the object proposed [Villalpando and Prado, 1604: vol 2, 63];” the eye contemplates exactly the same thing when it examines the lines planned in a given surface that includes the object itself. It must preserve the same order and the same distribution that there is preserved in the objects.

"Finally we have concluded, and this should remain perfectly clear that you" "will not see the distances of objects and that species normally excite the" "vision in this way, since they occurring away from an object, an object that" "is close, although they excite the vision with greater force than the distant" "objects more closely represent the parts of the object, which they cannot" "achieve [Villalpando and Prado, 1604: vol 2, 63].”

Villalpando claimed that this can be demonstrated by means of mathematics; the straight lines are laid out from all the parts of the object toward the eye, where its species are received; in considering any surface between the object and the view sighted, this will cut all the lines cited and they will reach the eye because the lines have been planned from the object across the surface. They will preserve the same disposition and distance for what it refers to as the limits of the lines; limits that have been received in the eye turns out to be totally extrinsic, although there is placed some prolonged lines, or equal ones, or some shorter and others even more prolonged.

"It follows that if someone marks on the surface the limits of the lines, so"

"that they can excite the vision, they will produce the same vision that were" 
"obtained earlier when they were coming from the object. But if a few" "lines are joined at the said limits of these lines, not only would they" "represent the indivisible limits of the visible object, but also the limits of" "their length: we call these lines and the physical points visible, not" "mathematical. These designed lines according to what we have just said," "if they are distinguished also by their shadows, in such a way they would" "deceive the human eye with objects similar to the one that remain" "represented by the lines, they would seem authentic [Villalpando and Prado, 1604: vol 2, 63].”

Vitruvius stated that the architect should know the art of painting to plan with facility. Villalpando claimed that this appears to imply drawing as a special class of instruction which is necessary to carrying out the works of the plan, elevation and perspective; it appears that Vitruvius evidently

"separated the skill of the science of optics, from the sciences of the" "architect, he specified respectively by separating optics and drawing," "granting to drawing the different sketches of the works and to optics the" "study of the brightness in the buildings and in other areas [Villalpando and Prado, 1604: vol 2, 63].”

Villalpando points out that this does appear to be the opposite to want he is saying since the purpose of his book was to recognize the assumptions that optics would be able to explain the descriptions of architectural drawing. He continued

"But if this theme is examined with attention, it will be discovered that" "there is something in common between optics and drawing, as between" "that part of geometry that deals with the intellectual refinement and the" "part that's purpose is to execute the work; to this part are called the" "practical part, and to the other speculative part [Villalpando and Prado, 1604: vol 2, 63]."

Although geometry is called the practical part, it cannot be understood completely if it does not adhere to the principles of the speculative geometry on the other hand nor can it be understood as some form of drawing that is the practical part of optics without some principles which have been taken from speculative optics.

Perspective represents the image of the building in totality already built with its façade and its sides in a single image;

"the presence of this building remains included in the cone (of vision) and" "if you think therefore it is cut by a flat surface, for example by a board or" "a parchment or a papyrus, and if you can image that the lines of all the" "limits of the building leave its track or plan in the surface, these tracks" "represent the same building before the eyes placed in the same distance, in" "the same way that this building remained represented by its own species." "The figure on this board will be called perspective, we already know how" "it differs from a painting: a painting realizes the same parts of the building" "with its colours and textures, for example the stones, the wood, the grids" "of iron; on the other hand the perspective represents the distinct parts of a" "building by means of lines and shadows [Villalpando and Prado, 1604: vol 2, 64].” 
For Villalpando, perspective was not restricted to the facades and the sides but also include the pavement and the ceiling; but "Vitruvius does not mention this because he appeared to consider that this was the function of the plan [Villalpando and Prado, 1604: vol 2, 65]."

However, this form of perspective requires a great deal of ability and art. Villalpando's purpose was to present a perspective of the entire Temple of Solomon. He claimed that

"frequently I have endeavoured in proposing an single perspective of the" "entire building and I have obtained it, but times also I desisted from this" "pledge, defeated by the difficulty of such a perspective and by the great" "deal of time that it requires of me; although I have not been able to" "translate the perspective of the entire temple, I have completed a" "perspective of the noblest and most important part of the Temple, that of" "the Sacred Sanctuary entitled: view of the vault, of the walls, of the" "pavement of the sacred Sanctuary and Testament together with the" "Cherubims [Villalpando and Prado, 1604: vol 2, 65]."

Although Villalpando stated that he did not lose hope of drawing a perspective of the entire Temple, the image of the Sacred Sanctuary is the only perspective in the entire three volumes of In Ezechielem Explanationes (see Figure 3). It is a haunting and mysterious interior of the most sacred part of the temple; it contains the Ark of the Covenant and the Cherubines that guard it. The Ark is not of the Biblical dimensions and Cherubines are more human and serene than the Biblical four faced guardians, part lion, part man with the wings of an eagle and the claws of a lion [Villalpando and Prado, 1604: vol 2, 88], in many ways this engraving contradicts the text that it is illustrating.

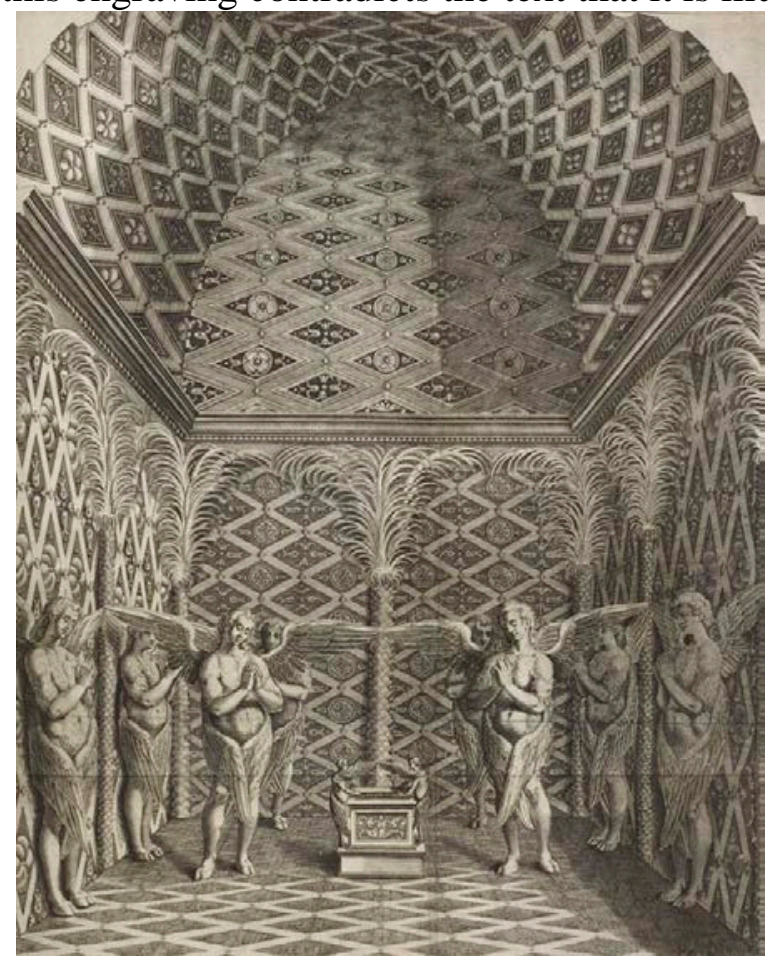

Figure 3: Villalpando: The view of the vault, of the walls, of the pavement of the sacred Sanctuary and Testament together with the Cherubims 
But Villalpando was attempting to propagate an entire theory of the nature and science of architectural drawing and not just perspective itself. The plan, elevation and perspective were all a form of optics and thus are all forms of perspective.

However, he defined two forms of vision one that is common and natural, in which sight is less than the object seen, and the other, where it can be imagined by using the example of light when the eye is supposed to be equal to the object seen. The visual species remains in the object but a cylinder will appear to be a circle or a rectangle this second form of vision he referred to as 'hypothetical vision.' The perspective requires the first way of vision; the plan and the elevation require the second way of vision. Similar to perspective the way of vision is cut to obtain the vision.

"However, in this section of the cylinder itself is something that is unique" "and exclusive to the plan and the elevation, and therefore we understand" "that it always takes place in a plane formed at right angles to the parallel" "figure; the contrary thing happens, as we have said, in the perspective," "because there we assume that the cone of vision is cut by a plane formed" "by any and every kind of angles. From this it is deduced that everything" "that is parallel to the vision is formed exactly equal, in the elevation and in" "the plan, to the same elements or parts of the building and keeping" "between itself the same proportion, therefore is originated from the cut or" "section, such cuts of a parallel figure is what we have referred to as the" "plan and the elevation [Villalpando and Prado, 1604: vol 2, 66]."

Villalpando goes to great length to explain this 'hypothetical vision,' using the same Aristotelian terminology as his theory of perspective. He continually referred to it as 'vision,' only using the term 'hypothetical' once, despite the fact that it has no focal point, all lines or rays are parallel, and it in no way relates to the vision he previously described. Although he refrained from using the term 'cone of vision' his repeated use of 'vision' implies some relation with perspective. Villalpando's use of Aristotelian terminology and his convoluted explanations often makes very simple concepts seem extremely complex and confusing. But he ends his description of the nature and science of architectural drawing with a clear example of an elevation.

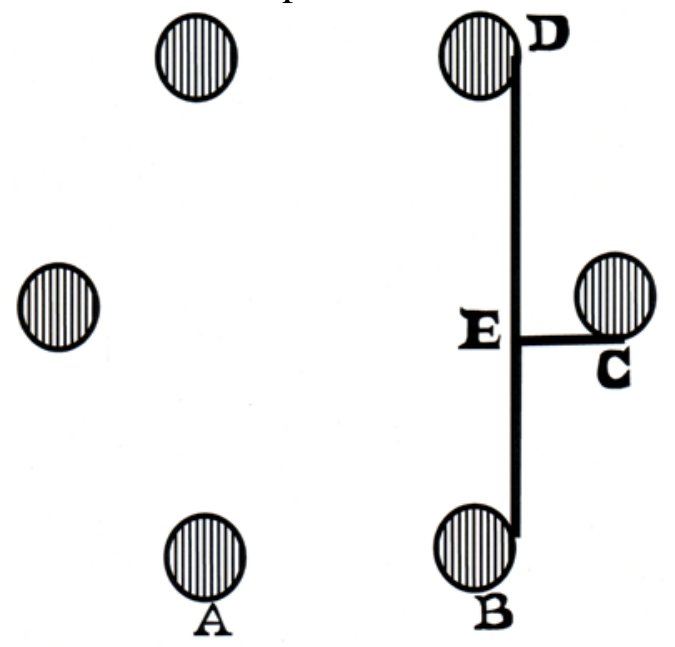


"It (the elevation) can be seen with clarity with the following example:" "ABCD be the building, of six columns A, B, C, D, etc, separated by equal" "inter-columns. If its facade is observed $A B$, since the vision is carried out" "through parallel lines cut at right angles, there will be seen the" inter"column AB, which is equal to the inter-column BC but it will not appear" "to be the same without depending on the distance of CE that lays parallel" "to $\mathrm{AB} ; \mathrm{BD}$ is in the line of the vision and perpendicular to $\mathrm{CE}$ next to the" "one that the section is carried out. As one cannot draw any perpendiculars" "to the parallel lines that are greater than the distance of the columns, they" "are considered almost perpendicular, it turns out that we cannot see any" "inter-column greater that the one that will in fact be built in the" "building[Villalpando and Prado, 1604: vol 2, 67];"

\section{Conclusion}

Throughout the text of Volume Two of In Ezechielem Explanationes, Villalpando quoted copiously from other authors to support he arguments or to refute their arguments. Yet in Book Two there is a stark contrasted in the lack of authors quoted. Villalpando was aware of the theories of Alberti and Serlio, both are mentioned elsewhere, but he does not mention either author in his discussion of perspective. Although he claimed that his purpose in Book Two was to create an "Architecture of Theology," so that through understanding the planning of Solomon's Temple the theologian could understand the Scripture, primarily Book Two is addressed to the architect and involves the practical application of perspective.

For Villalpando perspective was the most adequate form of architectural drawing it does justice to the symmetry but "the perspective cannot achieve the adequate proportion of all the work and of all their parts." All three forms of architectural drawing are required. The perspective drawing was required for the first way of vision - the cone of vision; while the plan and the elevation are required for the second way of vision - the cut section of the cone of vision, which in the case of the plan and elevation is a cylinder.

For Villalpando the profane is a copy of the sacred. To understand the practical science, the architect of the copy should to be able to read and comprehend architectural drawings this was to glimpse the sacred. After all the

"figure or image of the house that was presented by Ezekiel, and that we"

"want to reproduce according to our possibilities, had to be a figure or"

"design to a smaller scale. That is to say, reduced to a smaller form;"

"unless, by means of this term, that is to be understood in the same way"

"that Vitruvius indicates, when he speaks of the 'reduced plan,' or of"

"“reducing the elevation of a building [Villalpando and Prado, 1604: vol”

"2, 91],”,

Ezekiel reduced the vision of the Temple to a reduced plan to convey the sacred by only using text. The 'composition' of the Temple was seen through the images of Ezechielem Explanationes, which were a mixture of plans, elevations and a single perspective which made it possible to contemplate the temple and guide people through the text of Ezekiel. Villalpando perceived perspective as a Divine invention from God which was inscribed into the sacred text of Ezekiel, which was a guide for architects to use in their propane architecture and in their attempt to mimic the divine. 


\title{
References
}

ARROYO-FURPHY, Susana, and Laura TOLTON. 2009. Appendix A: Documents Pertaining to the Dispute between Father Villalpando and Father Prado. In Juan Bautista Villalpando's Ezechielem Explanationes: A Sixteenth-Century Architectural Text, Tessa Morrison, ed. Lampeter, New York: Edwin Mellen, 573-78.

LOYOLA, Saint Ignatius of. 1996. Personal Writings: Reminiscences, Spiritual Diary, Selected Letters Including the Text of the Spiritual Exercises. Joseph A Munitiz and Philip Endean, trans. London: Penguin.

MORRISON, Tessa. 2009. Juan Bautista Villalpando's Ezechielem Explanationes: A Sixteenth-Century Architectural Text. Lampeter, New York: Edwin Mellen.

RIPOLL, Antonio Martinez. 1991. El ‘Taller’ De Villalpando. In Dios Arquitecto, Juan Antonio Ranirez, Rene Taylor, Andre Corboz, Robert Jan Van Pelt and Ripoll Antonio Martinez, eds, Madrid: Ediciones Siruela, 243-84.

VILLALPANDO, Juan Bautista, and Jerónimo del PRADO. 1604, Ezechielem Explanationes Et Apparatus Urbis Hierolymitani Commentariis Et Imaginibus Illustratus. Roma, 1604

\begin{abstract}
About the Author
Dr Tessa Morrison is an Australian Research Council post-doctoral fellow in the School of Architecture and Built Environment at the University of Newcastle, Australia. Her academic background is in history, mathematics and philosophy. Her current research project focuses on sixteenth and seventeenth century sacred architecture. She has published articles on geometric, spatial symbolism and architectural history; her book publications are Juan Bautista Villalpando's Ezechielem Explanationes: A SixteenthCentury Architectural Text. Lampeter, New York: Edwin Mellen, 2009 and Labyrinthine Symbols in Western Culture: An Exploration of their History, Philosophy and Iconography, Saarbruecken,VDM Verlag, 2009.
\end{abstract}

